\title{
KOMPLEX ELEMZÉSI MÓDOK A VEGYIPARI GÉPÉSZET TERÜLETÉN
}

\author{
Petrik Máté \\ tanársegéd, Miskolci Egyetem, Energetikai és Vegyipari Gépészeti Intézet, \\ Vegyipari Gépészeti Intézeti Tanszék \\ 3515 Miskolc, Miskolc-Egyetemváros, e-mail: petrik@uni-miskolc.hu
}

Jármai Károly

egyetemi tanár, Miskolci Egyetem, Energetikai és Vegyipari Gépészeti Intézet, Vegyipari Gépészeti Intézeti Tanszék

3515 Miskolc, Miskolc-Egyetemváros, e-mail: altjar@uni-miskolc.hu

\section{Szepesi L. Gábor}

egyetemi docens, Miskolci Egyetem, Energetikai és Vegyipari Gépészeti Intézet, Vegyipari Gépészeti Intézeti Tanszék

3515 Miskolc, Miskolc-Egyetemváros, e-mail: szepesi@uni-miskolc.hu

\begin{abstract}
Absztrakt
A vegyipari gépészet területén belül öt nagyobb területet lehet felsorolni, melyek a müvelettan, szilárdságtan, áramlástan, biztonságtechnika és rendszertechnika. A különbözö tervezési és ellenörzési feladatoknál azonban nem lehet élesen szétválasztani ezeket a részterületeket, gyakorlatilag minden esetben komplex módon kell a problémát megközeliteni. Jelen cikkünkben ilyen komplexen vizsgált rendszerekre szeretnénk néhány jellemzö példát bemutatni.
\end{abstract}

Kulcsszavak: vegyipari gépészet, müvelettan, szilárdsági méretezés

\begin{abstract}
Within the field of the chemical engineering five major areas can be mentioned, which are the unit operations, the structural design, fluid engineering, safety engineering and system technique. However, in the case of different design and checking tasks, it is not possible to sharply separate these minor areas. In the practice, all problem must be approached in a complex way. In this present paper, some typical examples of complex systems would be presented.
\end{abstract}

Keywords: chemical engineering, unit operations, structural design

\section{Bevezetés}

A vegyipari műveleteket nagyon leegyszerüsítve úgy lehetne definiálni, hogy vagy több anyagot szeretnénk egymással egyesíteni, vagy egy heterogén rendszer alkotóit szeretnénk egymástól szétválasztani. A vegyipari gépészet alapfeladata pedig ezen vegyipari technológiák végrehajtása, rendszerbe foglalása és a hozzá tartozó berendezések megtervezése [1]. A hétköznapi életből példákat hozva ide sorolhatóak szeszgyártási technológiák (a kiindulást jelentó cefre alkoholtartalma túlságosan alacsony, desztillációs müvelettel a végtermékben feldúsítjuk), környezetvédelmi technológiák (a füstgázokban lévő kén kalcium-tartalmú vízzel érintkeztetve leválasztható, így nem kerül a légkörbe és 
nem okoz környezetkárosító kénesőt) vagy a legkülönfélébb müanyagok gyártása (melyek kiindulási anyagát a kőolajfinomítók különböző termékeiből állítanak elő) [2].

Ezek a legkülönfélébb technológiák a környezetitől eltérő nyomáson és hőmérsékleten mennek végbe, melyekhez nyomástartó berendezéseket kell gyártanunk. Ezek a készülékek mindig valamilyen rendszerben müködnek (a reakció beindításához bizonyos hőmérsékletre és nyomásra van szükség). A hőmérséklet növelésének bevált módszere a gőzfütés, melyet egy hőcserélővel tudunk biztosítani. A nyomásfokozást valamilyen szivattyú vagy kompresszor fogja elvégezni, azonban mivel ezek a berendezések az üzemek „szívei”, védeni kell a szennyeződésektől. Ezek jelentkezhetnek szilárd anyag formájában, melyeket egy szürőberendezéssel választhatunk le, vagy jelentkezhetnek gázbuborékok formájában, melyeket valamilyen gáztalanító berendezéssel távolíthatunk el [3].

Mai modern világunkban a népesség növekedésével mind az élelmiszer, energia és árufogyasztás is fokozatosan növekszik. A vegyipari gépészetnek mindhárom szektoron belül jelentős szerepe van.

$\mathrm{Az}$ energiatermelés helyszínei az atom- és fosszilis tüzelésű erőmüvek, ahol előbbi esetben a radioaktív anyagok hasadásából, utóbbi esetben a biomassza anyagok elégetéséből származó hő segítségével gőzt fejlesztünk, mellyel munkát végeztetünk egy turbinán. Az élelmiszergyártás esetén számtalan jellemző példát lehet hozni:

- $\quad$ szeszes italok gyártásánál a desztilláció és rektifikálás müveletét,

- $\quad$ lekvárok, szirupok, tengervíz sótalanítása esetén a bepárlás műveletét,

- $\quad$ cukorgyártás esetén a mechanikai műveleteket, extrakciót, kristályosítást,

- gabonák feldolgozása esetén az őrlést, osztályozást, pneumatikus szállítást.

Ennél a pontnál szeretnénk felhívni a figyelmet arra, hogy a felsoroltak ugyan mindegyike emberi fogyasztásra alkalmas, adott körülmények között potenciális veszélyforrásként viselkedhetnek (a etilalkohol gőze éghető, a por formában lévő anyagmennyiségek megfelelő méret- és koncentrációtartományban robbanásra hajlamosak).

Ebből a rövid felsorolásból is érezhető, hogy a gépészmérnöki tudományok területén belül jelentős szerepet képvisel a vegyipar. Természetesen ennek a tudományágnak a fejlődése nem mehetne végbe a többi, klasszikusként is definiálható terület fejlődése nélkül. Mindenki célja, hogy ezt a szinergikus kapcsolatot fenntartsa. Valamint elmondható az is, hogy ezen a területen belül is komplex gondolkodásmódra van szükség, a hatékonyság növeléséhez a csoportmunka elengedhetetlen. Jelen cikk célja, hogy egy rövid betekintést nyújtson ezek közé a komplex feladatok közé.

\section{Növelt felületü hőcserélők vizsgálata}

Az elsőként bemutatásra kerülő tématerület a növelt felületü, vagy bordáscsöves hőcserélők vizsgálata. Ha a kompresszorok nevezhetők az üzemek szívének, akkor a hőcserélők az igáslovak. Nem csupán üzemi, hanem a háztartások és a jármüipar is széles körben alkalmazza őket. Feladatuk kettős: egyrészt biztosítani az adott müvelethez szükséges hőmérsékletet, másrészt a különböző folyamatok közben keletkező hő felhasználása. Utóbbira jó példa lehet a járművekben található radiátorok. Hagyományos belső égésü motorok esetén a hengerekben bekövetkező robbanás höje a motorblokkot egy folyamatos höárammal látja el, melynek következtében a blokk hőmérséklete növekedni fog, mely viszonylag rövid idő alatt müködésképtelenné teheti. Ennek elkerülése érdekében a blokkban csatornákat képeznek ki, melyben hütőfolyadékot keringtetnek. Itt a hütőfolyadék felmelegszik, hőt von el a motorblokktól, mely hőt a radiátorban a levegőnek adja át. A 2020-as évek áttörését az elektromos autók térhódítása fogja jelenteni, melyben elektromos motor fogja a hajtást biztosítani, viszont ezekben is szükség lesz ilyen hütőkre, csak nem a motor hütésére, hanem az akkumulátorcellák hütésére. 
Az ilyen típusú berendezések vizsgálatához megterveztünk egy mérökört, mellyel gyakorlatilag minden kisebb méretü hőcserélő berendezés vizsgálata elvégezhető [4-5]. Ennek a mérőkörnek a sematikus rajzát az 1 . ábra mutatja.

A jármüvekben található síklemez-bordás hőcserélők másik elterjedt felhasználása a légkondicionáló berendezések külső egységében történik. Itt is említhetők a háztartásokban felhasznált berendezések, ipari szempontból viszont sokkal nagyobb teljesítményekröl beszélhetünk. Erre példaként hagy hozzuk a nagy üzemek számítógépparkját. A rengeteg mért jellemző (hőmérséklet-, nyomás-, összetétel- és folyadékszint értékek), a szabályozó és vezérlő jelek ezekbe a számítógépekbe érkeznek, melyek müködésük során rengeteg hőt termelnek, ezért az egész termet, ahol ezek elhelyezkednek, hüteni kell. A komplex gondolkodásmódra és együttmüködésre itt a villamosmérnökökkel és informatikusokkal történő kooperációt szeretném megemlíteni, akik nélkül mind a mérési, mind a beavatkozási lehetőségek sokkal korlátozottabbak lennének.



1. ábra. Höcserélők termikus tulajdonságai méréséhez tervezett mérökör sematikus ábrája

A mérés a következőképp múködik: a melegvíz tartályt vízzel feltöltjük, mely elektromos fütőszálak és egy hőmérsékletszabályozó segítségével a kívánt hőmérsékletig melegíthető. A melegágba be van építve egy keringtető szivattyú, mely ennek a közegnek az áramlását fogja előidézni. Ennek a szivattyúnak a szállítómennyisége állítható, így több üzemállapot kimérésére is lehetőség van. A pontos térfogatáram méréséhez egy rotaméter használható. Ezután van bekötve a vizsgálandó hőcserélő, melyből a lehütött közeg visszavezetődik a tartályba. A hőcserélő előtt és után a hőmérsékletek mérése számítógép segítségével történik. Attól függően, hogy milyen típusú a vizsgált hőcserélö, többféle módon is megoldható a hütése:

- $\quad$ autóradiátor esetén a ventilátor rá volt építve a radiátor házára, mely a levegő áramlását biztosította. Ebben az esetben frekvenciaváltóval biztosítottuk a ventilátor több fordulatszámát. A mérések során az átlagos légsebesség, a levegő átlaghőmérsékletét és nedvességtartalmát, valamint a radiátort elhagyó levegő hőmérsékletét kellett mérnünk.

- Egy bordás hajtúcsöves csőregiszter mérése szélcsatornában történt. A szélcsatornában különféle légsebesség mellett lehetett méréseket végezni. 
- Vízszintes orientációjú cső a csőben hőcserélő belső terében kialakuló kondenzáció vizsgálatánál a köpenytérbe vezetett hútővíz segítségével végezhetők mérések. Itt a gőzmennyiséget az időegység alatt lekondenzálódott víz mennyiségének méréséből lehet meghatározni.
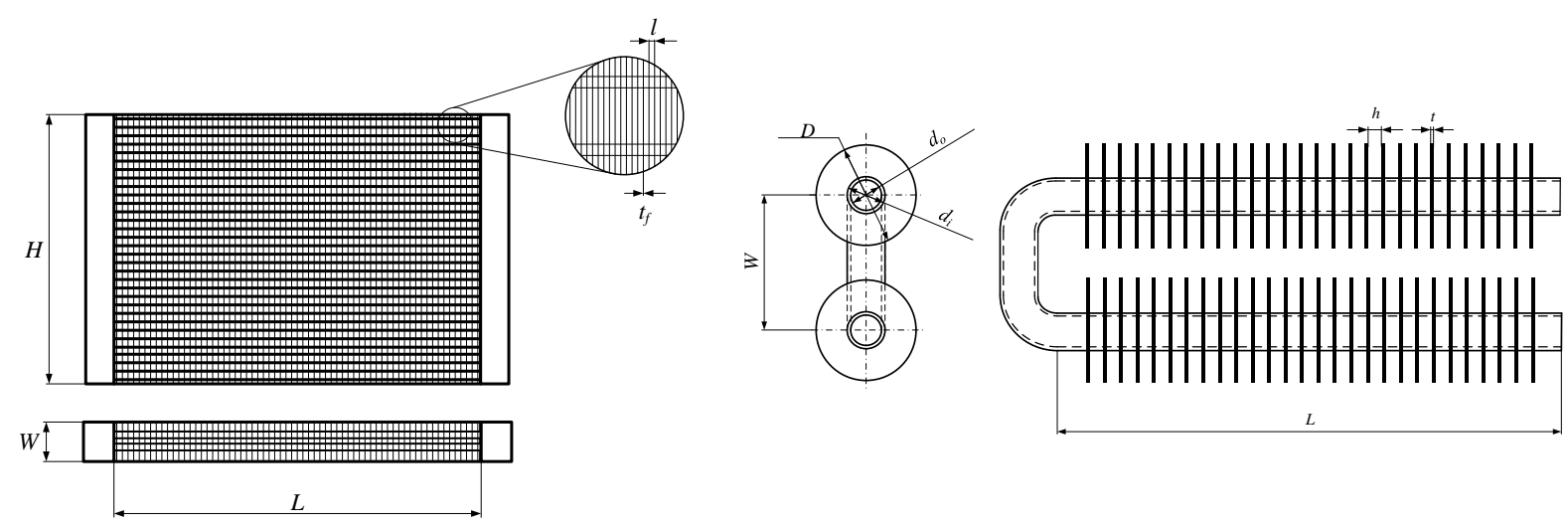

2. ábra. A vizsgált höcserélök sematikus ábrája

Az első két mérés mérési eredményeiböl sikerült a szakirodalomban található összefüggéseknél sokkal pontosabb Nu-szám összefüggést meghatározni. A harmadik mérés eredményeinek feldolgozása jelenleg is folyamatban van.

A 2. ábra bal oldalán látható radiátor hőtechnikai számításaihoz szükséges általunk meghatározott Nu-szám összefügés

$$
\mathrm{Nu}_{a}=0.817 \cdot \mathrm{Re}_{a}^{0.6} \cdot\left(\frac{A}{A_{t 0}}\right)^{-0.39} \cdot \operatorname{Pr}_{a}^{1 / 3}
$$

míg a csőregiszter esetén a következő:

$$
\mathrm{Nu}_{a}=29,59 \cdot \operatorname{Re}_{F}^{0,237} \cdot \operatorname{Pr}_{a}^{1 / 3}
$$

\section{Hőcserélők rezgéstani vizsgálata}

Ahogy az előző fejezetekben is látszik, bármilyen berendezésről van is szó, nem lehet csak és kizárólag egy szemlélettel hozzálátni a tervezéséhez. Az 1. ábrán látható melegvíztartálynak és 2. ábrán látható hőcserélőknek ugyanúgy ki kell bírni a szivattyú által létrehozott nyomást (a keringető szivattyú ugyan csak minimálisan növeli a közeg nyomását, de a biztonságos müködéséhez a légköritől nagyobb nyomás szükséges, mert a szerelvényeken áthaladva nyomásesést szenved el). A nyomáshatároló szerepen túl a dinamikus terheléseket mutatjuk be. Kisebb méretű berendezések esetén ennek nincs nagy jelentősége, viszont nagyobb berendezések esetén komoly problémákat okozhat [6].

Az ipari gyakorlatban leggyakrabban használt hőcserélő típusok a csőköteges hőcserélők. Ezek esetén viszonylag kis térfogatba nagymértékü hőátadó felületeket lehet elhelyezni. Ahogy az 1. és 2. összefüggésből is látszik, a kialakuló hőátadási tényező a Re-szám, vagyis a közegsebesség függvénye. Minél nagyobb sebességgel áramlik a közeg, annál nagyobb lesz a hőátadási tényező, így a berendezés höteljesítménye is [7]. 


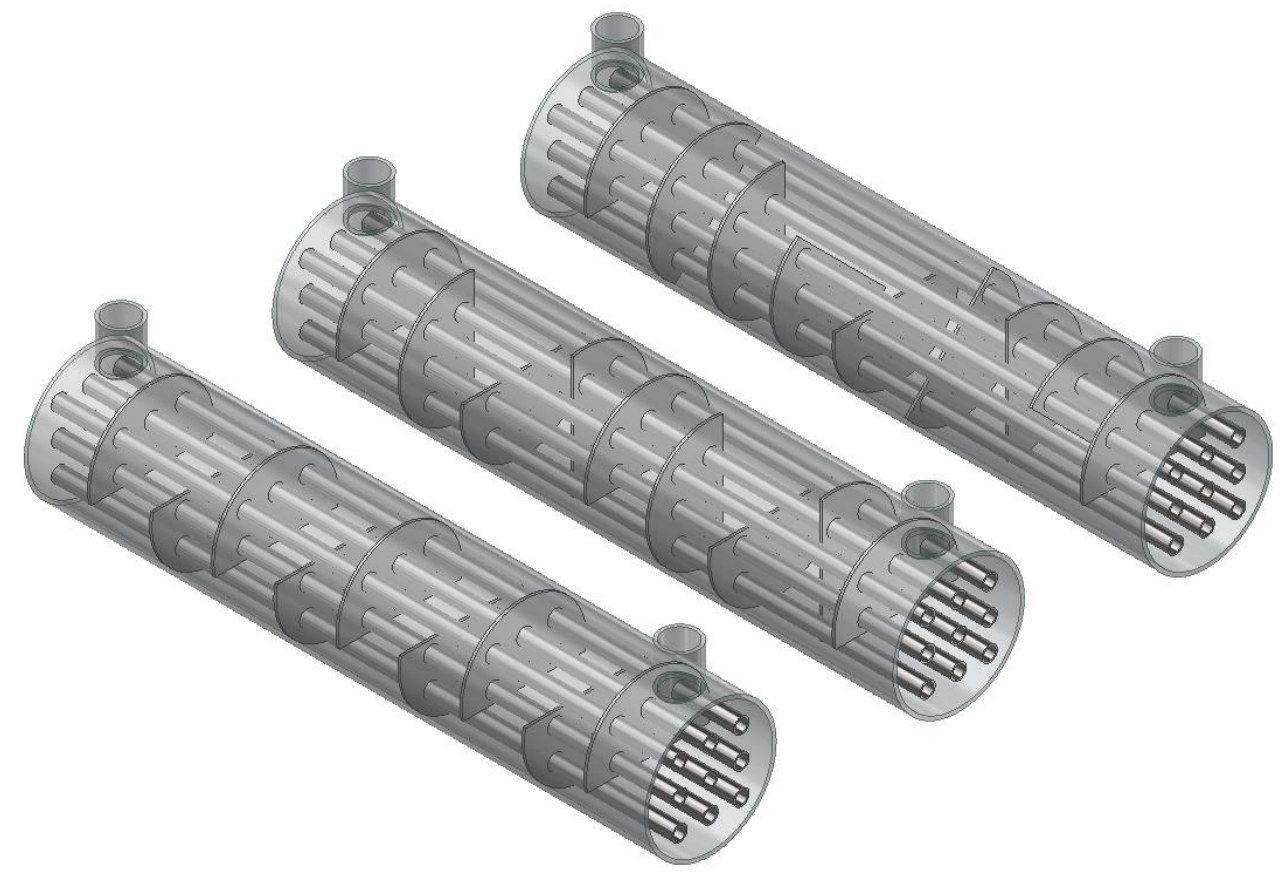

3. ábra. Köpenytérben elhelyezett különbözö terelölemezek

A köpenytéri közeg a külső hengeres héj és a benne lévő hőátadó csövek között áramlik, ami már így is egy csökkentett keresztmetszetet jelent, azonban sok esetben szükséges tovább csökkenteni ezeket. Ennek oka egyrészt a közegsebesség növelése, másrészt a höátadásban részt nem vevő térfogatok, pangó térrészek, angol meghatározással dead zone-ok csökkentése.

A 3. ábrán látható, hogy ezeket a terelőlemezeket egymáshoz képest többféle módon is elhelyezhetjük. Amiatt, mert az áramlási térben elhelyezünk ilyen lemezeket, az áramlási keresztmetszet le fog csökkeni, vagyis a Re-szám értéke, így a hőátadási tényező értéke növekedni fog. Ezzel szinkronban a berendezés nyomásvesztesége is növekedni fog. Ez üzemeltetés szempontjából káros, viszont mindkét értéket a tervezés során figyelembe lehet venni, akár egy optimalizálási feladatot is lehet végezni ezek felhasználásával. Azonban sokkal nagyobb problémát jelenthetnek a rezgések. A terelölemeznél a közeg felgyorsul, két lemez között lelassul, majd újra. Nagy sebességnél kisnyomási energia, kis sebességnél nagy nyomási energia fog folyamatosan váltakozni a hőcserélő tengelye mentén, mely rezgést fog okozni a berendezés belsejében. Ennek a rezgésnek az amplitúdója és rezgése CFD szimuláció alkalmazásával, míg a köpeny teherviselö képessége VEM alkalmazásával történhet.

Egy csőköteges hőcserélő végeselemes szimulációjának eredményei láthatók a következő ábrákon. A 4. ábra a vizsgált berendezést mutatja, melyben a csőköteget megfogásokkal helyettesítettük.

A vizsgálathoz az ANSYS környezet sajátfrekvencia meghatározására szolgáló modulját alkalmaztuk. Az elemzések során, valamint a hálófüggetlenségi vizsgálatok alatt a berendezésnek csupán az első hat sajátfrekvencia értékét kerestük. Azonban nem is kellett többet, mert a szakirodalomban találtunk olyan szivattyút, melynek a sajátfrekvenciája nagyon közel esett a hőcserélő sajátfrekvenciájához, mely gyakorlatilag azt jelentette, hogy valamilyen szilárdsági áttervezésre van szükség [8]. 

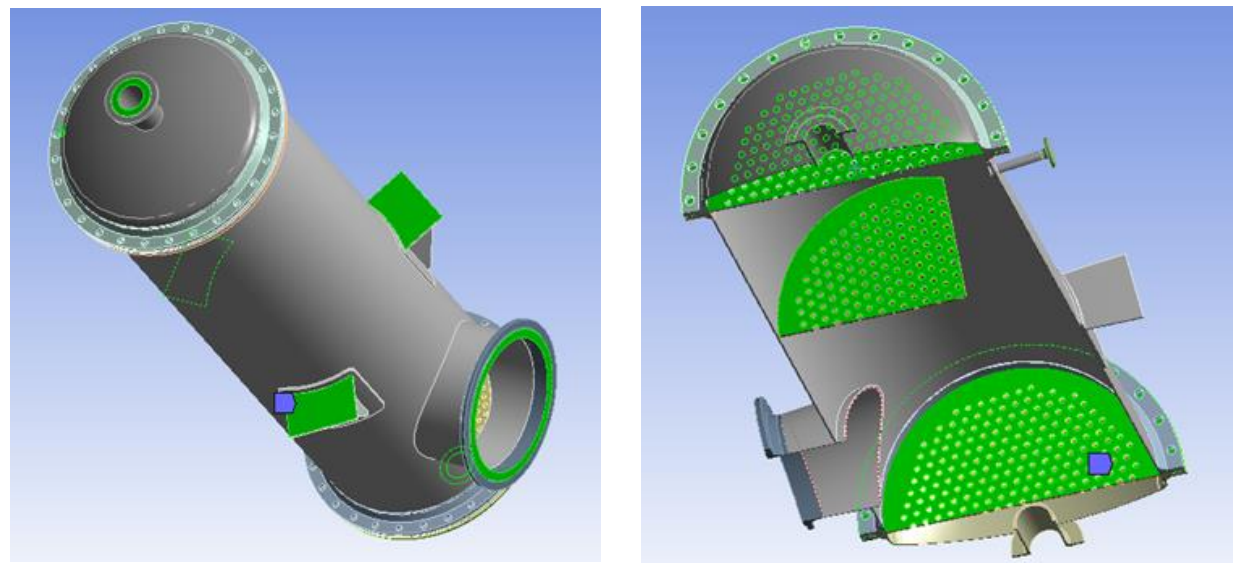

4. ábra. A vizsgált höcserélö köpenyterének modellje, a megfogásokkal

Hasonló rezgéstani problémák számtalan egyéb helyen kialakulhatnak. Egyik ilyen témakör a keverős készülékek területe. Keverős berendezések a hőátadási folyamtok elősegítését, a reakciók beindítását, anyagok homogenizálását, kristályosítás, folyadékban oldott gázok eltávolítását segíthetik elö. Ezen berendezések legfontosabb alkatrésze a keverőtengely, melyen a keverőlapátok helyezkednek el [9]. A lapátok száma általában 3-4, de még nyitott turbinakeverőknél sem haladja meg a 8-10 lapátot. A forgás következtében a lapátok hatnak a folyadékra, ami mozgásba lendül, és ez a mozgó folyadék pedig hatással lesz a készülékben található többi elemmel, amik áramlástörők, fütőcsőkígyók, vagy amennyiben nagyobb méretekben gondolkozunk, komplett csőkötegek is lehetnek. Ilyen esetben hasonló elemzéseket kell végezni: meg kell vizsgálni, hogy adott fordulatszám és geometriai méretek mellett milyen erőhatások, nyomáshullámok alakulnak ki a vizsgált térfogatban, majd az itt kapott eredményeket a szerkezeti elemekre külső terhelésként kell megadni. Amennyiben az eredmények szerint nincs jelentős hatással a kialakuló rezgések a szerkezeti elemekre, a berendezés rezgéstani szempontból üzemeltethető.

\section{Acélszerkezetek vizsgálata}

Az acélszerkezetek minden gyár, üzem alapvető részét képezi, gyakorlatilag azok csontvázát jelentik. A beruházás során, az építkezés kezdetén nagyon erőforrásigényes ennek a szerkezetnek a beépítése. Az üzemhez készített tervek során gyakorlatilag már egy optimalizálási folyamat zajlik; elvi korlátja nem lenne annak, hogy ezeket az üzemeket jelentősebb acélszerkezet nélkül, vertikális építési móddal építsék meg, valamint annak sem, hogy nagyon magas épületekben történjen a termelés. A vertikális építési módnak a hátrányai közé tartozik az, hogy nagyon nagy területre lenne szükség, ami a mezőgazdasági területek méretének csökkenését okozná, valamint a közegek áramlását nem tudnánk gravitációs módon megvalósítani, így sokkal több szivattyúra lenne szükség, amely az üzem energiafogyasztását növelné meg túlságosan (ami folyamatos kiadást jelent). A nagyon magas vázszerkezeteknél nagyon nagy szelvénykeresztmetszetekre lenne szükség, egyrészt a szerkezet öntömegének következtében, másrészt a rajta elhelyezett készülékek tömegéből. Egyik szélsőséges esetben sem elhanyagolható a kezelöszemélyzet beavatkozásának ideje sem, mely egyik esetben sem ideális [10-11].

Önálló példa esetén is van jelentőségük, gondoljunk például a 2 . fejezetben bemutatott klímarendszer külső egységére. Már a kisebb üzemek esetén is a számítógépszoba jelentős hütést 
igényel, melyhez nagy teljesítményű hütőberendezést és nagy felületű bordás hőcserélő tartozik. Ezeket általában vagy a szerverterem, vagy a vezérlőépület tetején szokták elhelyezni. Nagy tömegü berendezések esetén az épület szerkezetében kell nagy keresztmetszetủ szelvényeket beépíteni. Ebbe a tömegbe a készülék teljes tömegét bele kell számítani, vagyis az acélszerkezet, a töltet, a szigetelés, a szerelvények és minden hozzá tartozó egyéb tartozék tömegét bele kell számítani. Gyártás- és hegesztéstechnológiai és a csatlakozási pontok kialakításának szempontjából a legjobb választás az Iés szekrényszelvények lehetnek, de más igénybevételek esetén cellalemezek alkalmazása is ajánlott. Utóbbira jó példa lehet a kompresszorok, szivattyúk talplemezei.

A rácsos tartók két végükön csuklókkal összekötött merev testekből állnak. Az így kialakított tartót az öt alátámasztó szerkezetekkel a már tanult kényszerek, támaszok kötik össze. A rácsos tartókat az esetek többségében a rudak végpontjaiban, a csuklókon terhelik a külső erők, tehát egy rudat csak a két végén levő csuklókban ébredő erők terhelnek. A két erő egyensúlyából következik, hogy ezeknek közös hatásvonalon kell müködni, tehát ez az egyenes a rúd két végén levő csuklót összekötő egyenes.

Amennyiben a rácsos tartót csak a csomópontjaiban ható erök terhelnek, a tartó rúdjai részben csak nyomottak, illetve részben csak húzottak. Tehát nem hajlítottak. Összetett tartók esetében akkor mondhatjuk, hogy a tartó merev, ha bármilyen teher esetében nyugalomban marad. Ez a merevség a statikailag határozott tartóknál akkor valósul meg, ha a kapcsolatot a legkevesebb kapcsolórúddal biztosítják. A szükségesnél több kapcsolórúd esetében a tartó határozatlan, ha a szükségesnél kevesebb a kapcsolórúd, akkor a tartó labilis.

Az olyan egyenes tengelyü vagy görbetengelyü rudakból álló tartószerkezetet, amelyben a rudak találkozásánál létrejövő csomópontok sarokmerevek, keretszerkezetnek nevezzük. Másik kevésbé szokásos elnevezésük: törttengelyü tartószerkezetek. A sarokmerevség azt jelenti, hogy a rúdvégek, amelyek a csomópontban találkoznak, külső erő vagy más egyéb hatás következtében egyformán mozdulnak el. Keretszerkezetnek nevezzük az egyenes rudakból sarokmerev kapcsolattal létrehozott, síkbeli vagy térbeli terhelést felvevő szerkezetet [12-13].

\section{Biztonságtechnikai alapok}

Jelen cikkünkben próbáltuk a bevezetöben leírt részfeladatokat egymással összekötni, melyben gyakorlatilag mindenhol valamilyen höátadási folyamatot kötöttünk össze egy másik részterülettel. ebben a fejezetben szintén a hőátadást kötjük össze, most a biztonságtechnikai szemlélettel. Itt két jelentősebb problémát mutatunk be, egy hőcserélő berendezésben bekövetkezett csőtörés hatását, valamint egy tüzbe került légtartály időbeli viselkedését.

\subsection{Höcserélőben bekövetkezett csőtörés}

Csőköteges hőcserélökben történt meghibásodás esetén azt kell feltételezni, hogy egyetlen cső törik el, mégpedig teljes keresztmetszetben. A valóságban a csövekben kialakuló feszültségállapot következtében biztosan nem ilyen típusú meghibásodás fog bekövetkezni, mivel a tangenciális feszültség lesz a jellemző feszültsége, melynek következtében hosszirányban fog a cső felszakadni. Ezt a keresztmetszetet azonban szinte lehetetlen meghatározni, ezért a biztonság irányába tévedve feltételezzük a cső keresztmetszetet, méghozzá úgy, hogy a törött cső mindkét részéből érkezik a nagyobb nyomású közeg [14-15].

\subsubsection{Gázokra és gözökre vonatkozó összefüggések}

Gázok és gőzök áramlása esetén a számításokat a kritikus viszonyok ellenőrzésével kell kezdeni. Ehhez a kritikus nyomást kell meghatározni: 


$$
p_{c r}=p_{1} \cdot\left[\frac{2}{\kappa+1}^{\kappa / \kappa-1}\right]
$$

- $p_{1}$ a nagyobb nyomású tér nyomása (psi)

- $\kappa$ az izentropikus kitevő (-)

A folyamat hajtóereje a nyomáskülönbség lesz, mely a következö összefüggéssel számítható:

$$
\Delta p=p_{1}-\max \left(p_{c r}, p_{2}\right)
$$

ahol $p_{2}$ a kisebb nyomású tér nyomása (psi).

$$
m_{b e}=2407,7 \cdot C \cdot A \cdot Y \cdot \sqrt{\Delta p \cdot \rho}
$$

- $C$ az átfolyási tényező

- csőből a köpenybe történő áramlásnál 0,74

- köpenyböl a csőbe történő áramlásnál 0,6

- $A$ az áramlási keresztmetszet (cső belső keresztmetszetének kétszerese), inch ${ }^{2}$

- $Y$ az expanziós kitevő, amelyet szintén a lefúvás irányának megfelelően kell meghatározni

- csőből a köpenytérbe történő áramlás esetén

$$
Y=1-0,4 \cdot \frac{\Delta p}{p_{1}}
$$

- köpenyböl a csőtérbe történő áramlás esetén

$$
Y=1-0,317 \cdot \frac{\Delta p}{p_{1}}
$$

- $\rho$ a nagyobb nyomású közeg sürüsége $\left(\mathrm{lb} / \mathrm{ft}^{3}\right)$

Az összefüggésekben látható, hogy az API-nak megfelelően az angolszász mértékegységekben helyettesítettük be a jellemző értékeket.

\subsubsection{Folyadékokra vonatkozó összefüggések}

Folyadékok átáramlása esetén nem kell kritikus nyomásviszonyokat számolni, hanem egyszerüen a két tér nyomáskülönbsége adja a folyamat hajtóerejét:

$$
m_{b e}=2407,7 \cdot C \cdot A \cdot \sqrt{\Delta p \cdot \rho}
$$

ahol

$$
\Delta p=p_{1}-p_{2}
$$

Ebben az esetben is meg kell különböztetni az áramlási irányokat, de a $C$ átfolyási tényező értéke nem változik ( 0,74 csőből köpenybe és 0,6 köpenyből csőbe történő áramlás esetén). 


\subsubsection{Készülék dinamikus modellje csőtörés esetén}

Abban az esetben, ha a vizsgált készülékben csőtörés következik be, akkor két lehetséges esetén állhat fenn:

- a köpenytérben lévő nyomás nagyobb, mint a csőtéri nyomás,

- csőtérben lévő nyomás nagyobb, mint a köpenytérben.

A második esetet vizsgálva tekintsük az 5. ábrát:

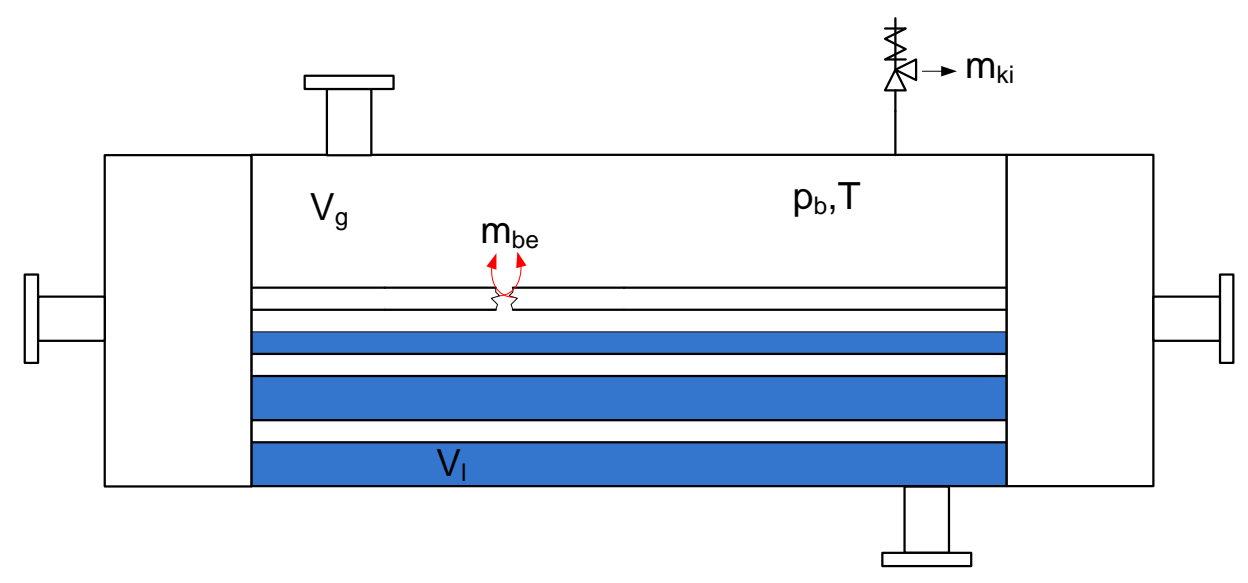

\section{5. ábra. A csőtörés egyszerüsitett ábrája}

Az ábrán látható egy hőcserélő vázlata, melyben lehet gáz és folyadék is $\left(V_{g}, V_{l}\right)$. A köpenytérben lévő kezdeti nyomást $p_{k}$-val jelöltük. A készülékbe csőtörés esetén anyag áramolhat be. A készülék el van látva biztonsági szeleppel, melynek nyitónyomását ps-el jelöltük. A készülék gázterében lévő nyomás meghatározásánál feltételezzük, hogy érvényes az ideális gáztörvény:

$$
p_{b}(\tau)=\frac{m_{g}(\tau)}{M_{g}(\tau) \cdot V_{g}(\tau)} \mathfrak{R} T
$$

Amennyiben a gáztérbe gáz halmazállapotú közeg áramlik be vagy olyan folyadék, ami az adott állapothoz tartozóan gáz halmazállapotúvá válik, úgy a gáztérben lévő anyagmennyiség megnő, valamint változik a gáztérben lévő molekulatömeg. Ha folyadék halmazállapotú közeg érkezik be kiforralódás nélkül, akkor ebben az esetben a rendelkezésre álló gáztérfogat csökken, ami szintén a nyomás növekedését okozza. A gáztér tömegének megváltozása az alábbi differenciálegyenlettel írható fel abban az esetben, ha gáz halmazállapotú közeg áramlik be:

$$
\frac{\mathrm{d} m_{g}}{\mathrm{~d} \tau}=m_{b e}-m_{k i}
$$

A készített program folyamatábrája a 6 . ábrán látható.

A modell vizsgálatánál egy $42 \mathrm{~m}^{3}$ térfogatú tartályt vizsgáltunk, melyen egy 3 bar ${ }_{\mathrm{g}}$ nyitónyomású biztonsági szelep van elhelyezve. A nagynyomású közeg 7,6 barg nyomású volt, míg a tartály a folyamat kezdetén atmoszférikus volt. A nyomásnövekedés számításához elengedhetetlen adat az edény töltöttségi szintje. Ezt változtatva összehasonlító grafikonokat készítettünk, melyről leolvasható a nyitáshoz szükséges idők. 


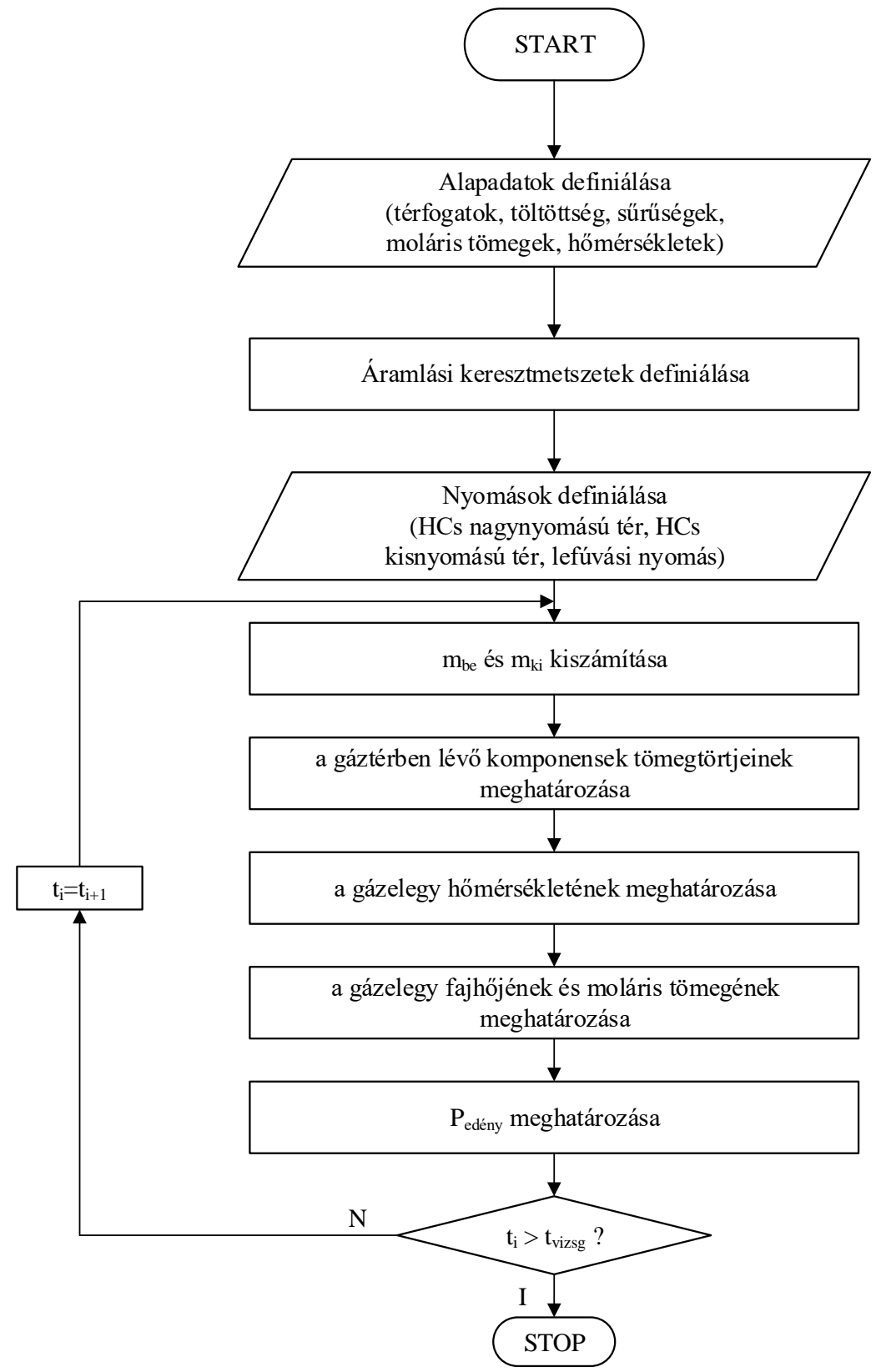

6. ábra. A dinamikus modell számitásának folyamatábrája,göz/gáz átáramlás esetén

Az ábrából jól látszik (ahogy várható is volt) minél inkább fel van töltve folyadékkal az edény, annál gyorsabban el fogja érni a nyomás a nyitónyomás értékét. A lefúvás bekövetkezte után a görbék fürészfog jelleget mutatnak. Ez a szelep nagy lefúvó keresztmetszetének a következménye. A nagy lefúvási keresztmetszet nagy lefúvási kapacitást fog eredményezni, mely megakadályozza, hogy a nyitónyomásnál nagyobb nyomás kialakuljon a rendszerben, viszont minden egyes fürészfog egy-egy nyitást reprezentál, ami káros a szelep élettartamára nézve. 




7. ábra. A vizsgált edényben lévö nyomás időbeli viselkedése, a töltöttségi szint függvényében

\section{6. Összefoglalás}

Jelen cikkben többféle olyan tervezési feladatot mutattunk be, melyek első ránézésre nem, egy tüzetesebb vizsgálat során viszont szoros kapcsolat fedezhető fel. Ezek közül az egyik legszorosabb kapcsolat a müvelettani és szilárdságtani vizsgálatok között van. Bemutattuk, hogy kísérleti módszerekkel hogyan lehet egy bordáscsöves hőcserélő hőteljesítményét meghatározni, milyen acélszerkezetet lehet hozzá építeni. Csőköteges hőcserélők esetén az áramlási jellemzőkből hogyan lehet rezgéstani jellemzőket meghatározni, mely a szivattyú kiválasztására is hatással van, valamint egy esetlegesen bekövetkező csőtörés esetén milyen módszerrel lehet a kisebb nyomású tér nyomását meghatározni.

\section{Köszönetnyilvánítás}

A bemutatott kutatómunka a Nemzeti Kutatási, Fejlesztési és Innovációs Hivatal (NKFIH) támogatásával a K 134358 számú projekt keretében valósul meg.

\section{Irodalom}

[1] Jourdan N. et al:: Compartmental Modelling in chemical engineering: A critical review, Chem. Eng. Sci., vol. 210, (2019) p. 115196. https://doi.org/10.1016/j.ces.2019.115196

[2] Fakhroleslam, M., Sadrameli, S. M.: Thermal/catalytic cracking of hydrocarbons for the production of olefins; a state-of-the-art review III: Process modeling and simulation, Fuel, vol. 252, (2019) pp. 553-566. https://doi.org/10.1016/j.fuel.2019.04.127

[3] Wagenfeld, J.-G., Al-Ali, K., Almheiri, S., Slavens, A. F., Calvet, N.: Sustainable applications utilizing sulfur, a by-product from oil and gas industry: A state-of-the-art review, Waste Manag., vol. 95, (2019) pp. 78-89. https://doi.org/10.1016/j.wasman.2019.06.002 
[4] Yao, J., A Review of industrial heat exchange optimization, IOP Conf. Ser. Earth Environ. Sci., vol. 108, no. 4, (2018) https://doi.org/10.1088/1755-1315/108/4/042036

[5] Taler, D., Taler, J., Trojan, M.: Thermal calculations of plate-fin-and-tube heat exchangers with different heat transfer coefficients on each tube row, Energy, vol. 203, (2020) p. 117806, https://doi.org/10.1016/j.energy.2020.117806

[6] Jo, J. C., Jhung, M. J.: Flow-induced vibration and fretting-wear predictions of steam generator helical tubes, Nucl. Eng. Des., vol. 238, no. 4, (2008) pp. 890-903. https://doi.org/10.1016/j.nucengdes.2006.12.001

[7] Abd, A. A., Naji, S. Z.: Analysis study of shell and tube heat exchanger for clough company with reselect different parameters to improve the design, Case Stud. Therm. Eng., vol. 10, no. October, (2017) pp. 455-467. https://doi.org/10.1016/j.csite.2017.10.002

[8] Zhao, W. Y., Ge, J. G., Ma, D. Li, C. M. Bao, S. B.:Vibration analysis of large centrifugal pump rotors, IOP Conf. Ser. Mater. Sci. Eng. OPEN, vol. 52, (2013) p. 022033. https://doi.org/10.1088/1757-899X/52/2/022033

[9] Singh, B.: CFD Simulation of mixing by maxblend impeller in a lab-scale anaerobic digester, (2019) pp. 23-24. https://doi.org/10.26649/musci.2019.010

[10] Xu, Y., Wang, Z., Zhu, Q.: An improved hybrid genetic algorithm for chemical plant layout optimization with novel non-overlapping and toxic gas dispersion constraints, Chinese $\mathrm{J}$. Chem. Eng., vol. 21, no. 4, (2013) pp. 412-419. https://doi.org/10.1016/S10049541(13)60490-6

[11] Wu, Y., Zhang, S., Wang, R., Wang, Y., Feng, X.: New model for large scale chemical industrial layout optimization, Chem. Eng. Res. Des., vol. 161, (2020) pp. 58-71. https://doi.org/10.1016/j.cherd.2020.06.026

[12] Farkas, J., Jármai, K.: Fémszerkezetek Innovativ tervezése. Miskolc: Gazdász-Elasztik Kiadó és Nyomda, 2015.

[13] Farkas, J., Jármai, K.: Analysis and Optimum Design of Metal Structures. Rotterdam, Hollandia: Balkema Publishers, 1997.

[14] Harhara, A., Hasan, M. M. F.: Dynamic modeling of heat exchanger tube rupture, BMC Chem. Eng., vol. 2, no. 1, (2020) pp. 1-20. https://doi.org/10.1186/s42480-020-0029-1

[15] Crane Technical Paper 410: Flow of Fluids Through Valves, Pipes and Fittings, Crane Valves, 2009. 